\title{
THE EFFECT OF AWARENESS, ASSOCIATION AND PERCEIVED QUALITY OF RETAIL ON SHOPPING INTENTION REGARDING MEDIATING ROLE OF LOYALTY TO RETAILING (CASE STUDY: NAJM HYPERMARKET IN RASHT)
}

\author{
Seyed Amin Eshaghi Klour \\ Department of business management, Rasht Branch, Islamic Azad University, Iran \\ seyed amin eshaghi@yahoo.com \\ Maryam Ooshak Saraie \\ Department of Industrial Management, Rasht Branch, Islamic Azad University, Iran \\ maryamooshaksaraie@yahoo.com
}

\begin{abstract}
Many organizations believed that one of their most valuable assets is brand of products and their services. Many researchers pointed out this subject that creating a powerful brand is one key factor for achieving competitive excellence and long-term survival in the market. A proper brand can strengthen his intention for shopping by stability in mind of consumer. Therefore the main goal of research is effect of awareness, association and perceived quality of retailing on shopping intention regarding mediating role of loyalty to retailing (case study: Najm hypermarket in Rasht city). Current research is applied one and regarding classification of research based on the way of data collection it is descriptive. Statistical society of research is all customers of Najm hypermarket in Rasht. Regarding that number of considering sample based on having the best condition is chosen for presenting proper information so sampling method is improbable and purposeful sampling method. For determining number of sample Cochran formula of unlimited society has been used and number of calculated sample is 352 customers of this shop. Tool of data collection in this research is standard questionnaire that has been designed by Das in 2014. For considering hypothesis of research confirming factor analysis and structural equation modeling has been used. Result of research denotes positive and meaningful effect of dimension of retail especial value on shopping intention. On the other hand effect of association of retailing, awareness of sale and perceived quality of retailing on customer's loyalty was confirmed.
\end{abstract}

Keywords: Shopping intention, Retail specific value, Hypermarket, SEM

\section{ALIŞVERISS NIYYETİ ÜZERİNDE ALGILANAN KALITENIN PERAKENDE SISTEMINDE FARKINDALIK, DERNEK VE PERAKENDE ETKISININ ROLÜ (VAKA ÇALIŞMASI: RAŞT İÇINDE NAJM HIPERMARKET)}

ÖZ

Birçok kuruluş kendi en değerli varlıklarından biri ürün ve hizmetlerinin marka olduğuna inanılmaktadır. Birçok araştırmacı, güçlü bir marka yaratma pazarda rekabetçi mükemmellik ve uzun süreli sağkalım elde etmek için bir anahtar faktör olduğunu bu konuyu işaret etti. Uygun bir marka tüketicinin zihninde istikrar 
alışveriş için niyetini güçlendirebilir. Bu nedenle araştırmanın temel amacı farkındalık, dernek etkisi ve perakende sadakat rolünü aracılık ilgili alışveriş niyeti üzerinde perakendeciliğin algılanan kalite (: Rasht kentinde Necm hipermarket vaka çalışması) 'dir. Mevcut araştırma bir uygulanır ve veri toplama yolunda dayalı araştırmaların sınıflandırılması ile ilgili bu açıklayıcı. Araştırmanın istatistiksel toplum Raşt içinde Necm hipermarket tüm müşteriler. En iyi durum doğru bilgi sunmak için seçilir sahip dayanan örnek göz önünde sayısının konusunda bu kadar örnekleme yöntemi imkansız ve amaçlı örnekleme yöntemidir. Sınırsız toplumun örnek Cochran formülü sayısının belirlenmesi için kullanılan ve hesaplanan örneklem sayısı bu dükkanın 352 müşter olmuştur. $\mathrm{Bu}$ araştırmada veri toplama aracı kullanılmıştır araştırma doğrulayan faktör analizi ve yapısal eşitlik modelleme hipotezi dikkate için 2014 yılında Das tarafından dizayn edilmiştir standart anket olduğunu. Araştırma sonucunda alışveriş niyeti perakende özel değer boyutunun olumlu ve anlamlı bir etki gösterir. perakendecilik dernek, satış bilinci ve müşteri sadakati üzerindeki perakendeciliğin algılanan kalitesi Öte yandan etkisi teyit edildi.

Anahtar Kelimeler: Alışveriş niyeti, Perakende spesifik bir değer, Hipermarket, SEM

\section{STATEMENT OF PROBLEM}

Organizations can use shopping intention as an index for predicting behavior of consumer. When consumers have positive tendency to shopping this subject is a positive commitment to a brand that directs consumers toward shopping (Wu et al, 35). Shopping intention is a motivating state of customers for shopping that has been known as consequence of perceived value of brand of product or service(Aghazadeh et al, 15, 2013).Estimating the degree of shopping intention of a customer distinguishes his future behavior based on his interests(Karimi Alavijeh and Kakaei Siahkal, 85, 2012) and this factor is a procedural Variable for estimating future performance of a customer against a brand(kim \& ko, 2012, 1482:Das, 2013).Satisfied customer have usually tendency to strong shopping, whereas dissatisfied customers tend to another competitor(Hsu et al, 2015). Therefore for measuring tendency to shopping it is supposed future behavior of consumers depends on their attitudes (Wu et al, $2015,34)$. Shopping intention of customers and information of them for organization has importance in decision-making like demand of product in future, sectioning market and making strategies of sale(Moller \& Herm, 2013, 439). Regarding that in research of Das(2014) retailing has been considered as a brand so in this research variables of awareness of retail, association of retailing, perceived quality of retailing and loyalty to retailing is considered(Das, 2014, 285)

Awareness of retailing in research model has been identified as equal of awareness of a brand as the first dimension of brand specific value. When a consumer has awareness and identification toward a brand this factor can play important role on their shopping intention. The aim of awareness is degree and present power that a brand has in mind of consumer, different methods that brand awareness assess and documents customers remembering the brand (Das,2014,287). Brand especial value to the much degree supports through awareness that consumers make about brand in their mind(Dehdashti et al, 81, 2012). Brand awareness pints this point that if consumers can distinguish a brand and call it and or more simpler does consumer know something about brand or not(Lu et al, 2015, 263).

Association of retailing in research model has been identified equal to brand as the second dimension of brand especial value. One key factor in success of marketing strategy is perceiving consumer's behavior against brands (Dehdashti Shahrokh et al, 84, 2012). A powerful brand by association in mind of customer creates value both for customer and organization (Hosseini et al, 13, 2013). Brand association may be observed in the form of all features and forms related to good or independent aspects of the good itself. Association is a basis for shopping decision for loyalty to a brand and creates value for companies and customers (Lu et al, 2015, 263). Researchers pointed out this subject that creating a powerful brand is a key factor for achieving competitive excellence and long-term survival in the market. A proper brand 
can strengthen his intention for shopping with survival and association on mind of consumer (Moller \& Herm, 2013, 441;Santo et al, 2013, 149, Das, 2014, 289).

Loyalty to retailing in research model has been identified equal to loyalty to a brand as the third dimension of brand specific value. Aaker defines brand as a situation that shows how it is probable a customer tend to another brand especially when hat brand creates change in price or other aspects of the good (Seyyed Javadin and Shams, 78, 2007). Loyal customers interpretative shopping tend to an specific brand more probably and increase their share of shopping from that specific brand and by positive wordof-mouth advertisement causes more success(Kamaruddin et al, 2015, 434). One significant feature of loyal customer to a brand is favoritism of a brand and neglecting other bands. In other word loyal customers have positive tendency and behavior toward repeating shopping in future (Aghazadeh et al, 18, 2013). Seeming loyalty as an assetsleads to creating plans for enhancing loyalty and it leads to increasing shopping intention in customer (Dehdashti Shahrokh et al, 84, 2012).

Perceived quality of retailing in research model has been identified as perceived quality of shopper about brand as the fourth dimension of brand specific value. Perceived quality of purchaser about value is resulted from existing relationship between quality and advantages that a customer perceives against the price that pays for it(Aghazadeh et al, 2013,17). Service quality leads to customer loyalty and saving profit for presenters of services and proper performance of the organization in subject of service quality changes organization to a proper station in the view of loyal customers (Chopra, 2015, 243). Perceived quality of brand is a kind of mental association of a brand that has reached higher level and considers the way of brad assets (Das, 2014, 288). Therefore activities related to a brand by increasing perception of brand leads to repurchase behavior(Aghazedeh et al, 2013,15).

Regarding analysis of research variables researcher intends to test research conceptual model in hypermarket. Because in recent years main changes has been done in shopping culture of customers and development of hypermarkets in the country, hypermarkets were less intended to fallow long-term relationship and due to indiscrimination of permanent customers out of temporary, they present equal services and behavior. Another important problem that faces hypermarkets with challenge is that they present their services and goods without attention to gender, income, education, personality, social position, interest and previous shopping if customers. Attention to the problem of privatization of service and goods and suggesting customers regarding features devoted to the same customer is less paid attention to hypermarkets and other great retail hypermarkets (Jalali Gorgani and Mehrani, 2013, 59). Nowadays hypermarkets face severe competition. In such condition increasing number of customers are equipped with high volume of information and have more risk-taking power. Theyacquire more value that achieve instead of others, are talented to change their shop as changing hypermarket by customer has been changed into a usual action and challenge for retailers. Therefore factors that affect degree of customer tendency to repurchase play vital role at performance and success of hypermarkets. Loyal customers not only have high degree of shopping continuity and increase profitability for the hypermarket but also they remind it with positive attitude. Therefore retailers spend expensive cost for strategies of saving and keeping customers that is due to lack of dominance on determining factors of customer's loyalty, these budgets are spent fr aspects that has the least effect on customer loyalty and increasing efficiency of hypermarkets(Jahandideh et al, 2012,1). Therefore by assessing effective factors of brand awareness, brand association, perceived quality and loyalty to a brand in the view of customers and effect of these variables on shopping intention of customers' researchers intends to fid proper answer to the main questions of research that has been identified below:

*how is the effect of awareness of retailing, association of retailing, perceived quality of retailing and loyalty to retailing on shopping intention of customers about Najm hypermarket?

*Does variable of loyalty to retailing have mediating role in relation between three factors of awareness of retailing, association of retailing and perceived quality of retailing with shopping intention of customers of Najm Hypermarket? 


\section{LITERATURE REVIEW}

Purchaseintention points customer's tendency to purchasing a product. Consumers buy the product when they believe that product presented quality or features of real product. Shopping intention is a combination of interest of consumers or customers while buying a product or probability of buying in future. Many studies reported an strong relationship between a procedure and attitude toward a brand or product (Wu et al, 2014,2). Intention of repurchasing is related to mental probability that a consumer will continue buying product or service in future. Previous studies confirmed that intention of customers or consumes of product or service is determined through level of satisfaction. In real meaning of the word satisfied customers have strong intention of shopping whereas dissatisfied customers tend to another competitor (Hsu et al, 2015,49). Some studies inferred that shopping intention is in fact tendency of consumer for buying an specific product at distinct time or situation (Ihtiyar \& Ahmad, 2014, 594). In the view of especial value theory retailers can facilitate lack of tendency of shopping intention by customer that fallows services through efficient solution of perceived inequality of customers. Shopping intention in fact can be considered as consequence of behavior. Based on theory of planned behavior this theory considers consequence of attitudes, norm principles and perceived behavioral control (Muhamad Yunus et al, 2014,146).

\section{AWARENESS OF RETAIL BRAND}

Awareness means the effect that a brand creates in mind of consumer. Brand awareness in basic concept is brand loyalty and directs brand choosing that affects perception and behavior of consumer. Brand awareness is not merely knowing the name of brand or having and seeing in advance but more need relations like name of a brand, symbol of a brand that are combined in mind of consumer. Brand awareness may be defined as a fundamental factor and process of makingrelationship. Without brand awareness, achieving effects of communication isn't possible(Yildirim \& Aydin, 2012, 698).Brad awareness means how customer can distinguish identified brand out of unidentified in decision-making situation for shopping and remember(Parhizkar \& Ebrahimi Abed, 2013, 64). Brand awareness emphasizes a kind of learning excellence for brand. Brand awareness increases market performance of a brand. Support of services is one of the primary factors of creating brand. In marketing consumer literature shows that brand performance helps creating brand awareness and vice versa(chitcharon et al, 2013,9).

\section{RETAIL ASSOCIATION}

Association points relation between brand and consumer (application) including tendency to consumer shopping and advising others. A force that causes a brand to place in minds of consumers and be affected is more due to experience. Brand association can predict repurchase, income of future and value of a company against other markets (Kia, 2012,94). Brand association for customers provides the possibility in conditions that there is some choices of a brand, the best choice is done through specific cases in mind. Brand association has close relationship with its specific type by customer (Parhizkar and Ebrahimi Abed, 2012, 64). Association of brans is anything related to brand in mind of customer (Ehsani and Javani, 2012,90). Aker in 2004 states three effective factors on association of company's ability: the way of doing work by a company and degree of its development. Company's innovation, degree of global identification of a company. Achieving degree of growth of marketing and general plans of a company and brand is effective among people. Awareness of a brand causes consumers can perceive high efficiency of a company better. Also they should present new products for people who want innovation. In a competitive market it is difficult to be able to find a factor that creates distinction than other products and know it as innovation(kia, 2012, 91).

\section{PERCEIVED QUALITY OF RETAIL}

Chowdhury \& Habrouk in 2001 stated that consumer reliance besides being basis of perceived quality causes behavioral loyalty. Perceived quality can be defined as customer perception of total quality or 
excellence of product or services regarding his expected goal in comparison with another choices. Perceived quality is total and intangible emotion about a brand. However perceived quality is usually based on key dimension. For perceived quality, identification and assessing its main dimension will be useful. When the relationship between a brand and quality of a product before relationship between attributes of product and quality is perceived consumers are more affected by perception of quality (Kia, 2012, 93). Perceived quality has been defined as customer perception of quality or general excellence of a product (service) regarding the goal that product (service)has had and comparing to other products(services) of market. This problem is a competitive necessity and many companies have changes client-orientation quality to a powerful strategy nowadays. Satisfied customer through meeting needs and priorities of customers (Dehghani soltani et al, 2013,92).

\section{LOYALTY TO RETAIL}

Loyalty is final organizational goal that has a product with specific brand. Priority or shopping preference of a specific brand in a rack of product by a customer names loyalty. Customers found out that their expected brand supplies healthy product compound having lvles of qulity with proper price. This perception of customer will be a basis for new repurchase (Ghasemi and Azizi Darzian, 2013, 79). Customer loyalty is a combination of customer probability for repurchase of similar supplier in future. Apparently customer loyalty has been distinguished as a dominating factor at determining organizational success of a business. In a study done by lam \& Burton (2006) they found that loyal customers will participate in repeated purchasing of a supplier and increases their share of purchasing of an especific supplier. They may provide some suggestions or participate in word-of mouth advertisement. In fact customer loyalty can decrease costs and increase profitability and also causes production of better profit (Kamaruddin et al, 2012, 433).

\section{METHODOLOGY}

Current research is counted a kind of applied research regarding classification of research based on the goal. Current research regarding classification of research based on the way of data collection is descriptive research that describes sample features and then generalizes these features to statistical society. Descriptive research includes some classification that this research is its surveying type. Statistical society of research is all customers of Najm hypermarket in Rasht city. Regarding that number of considered samples based on having the best conditions, for presenting proper information is chosen, therefore sampling method is improbable and purposeful. Research questionnaire is standard that has been designed by "Das" in 2014. This questionnaire after translation and localization in this research has been used. The se $t$ of questions has been mentioned in the form of questionnaire but includes two separate sections. The first section is related to demographic information of respondents. In this section 6 questions related to gender, age, marital status, education, time of purchase from hypermarket and duration of purchasing from Najm hypermarket were asked. !7 next questions are related to independent, mediating and dependent variables of research conceptual model. Information related to questions of questionnaire have been mentioned in Table (1) regarding number of questions and references:

Table 1: Questionnaire information

\begin{tabular}{|c|c|}
\hline Variables of model & Number of questions \\
\hline Awareness of retailing & 3 \\
\hline Association of retailing & 5 \\
\hline Perceived quality of retailing & 4 \\
\hline Loyalty to retailing & 3 \\
\hline Shopping intention & 2 \\
\hline
\end{tabular}




\section{VALIDITY AND RELIABILITY OF QUESTIONNAIRE}

In order to be certain about result of measurement and in simple word claim that data resulted from measurement are reliable, measurement has two features of reliability and credit. In this research by using cronbach alpha reasonable compatibility between questions of questionnaire have been assessed. For considering content validity research questionnaire has been given to experts and authorities and in some sessions their considered reforms was acted on structure and content of questionnaire. Also for more consideration of reliability of questionnaire $\mathrm{KMO}$ and Bartletts for variables and the whole questionnaire was calculated that its result has been shown in table (3). After designing and writing questionnaire and confirming it by experts research is going to determining the degree of reliability of questionnaire. Therefore a primary sample including 30 questionnaires was pretested and then by using obtained data of this questionnaire and through statistical software of spss degree of reliance coefficient was calculated for this tool by cronbach alpha method. Amount of cronbach alpha for all index of research and also amount of this coefficient for the whole questionnaire was above 0.7.exact amount of these coefficients has been mentioned in table (2):

Table 2: reliability coefficient of variables of questionnaire

\begin{tabular}{|c|c|}
\hline Model variables & Cronbach alpha coefficient \\
\hline Awareness of retailing & $0 / 752$ \\
\hline Association of retailing & $0 / 763$ \\
\hline Perceived quality of retailing & $0 / 705$ \\
\hline Loyalty to retailing & $0 / 884$ \\
\hline Shopping intention & $0 / 750$ \\
\hline
\end{tabular}

\section{CONFORMATORY FACTOR ANALYSIS}

In this section two important output of lisrel software in standard solution and meaningfulness coefficient is presented:

\section{MODEL IN STANDARD SOLUTION MODE}

This estimation is called standard estimation mode. It is convergent coefficient that is their scale has become alike and there is the possibility of comparison. In a mode that this amount between hidden and apparent variables related to them is seemed equals with the same coefficient of correlation or factor loads (in doing confirming factor analysis) and if it is considered between two hidden variables, are the same coefficient of direction or regression standard $\beta$. Factor loads in standard in standard estimation shows degree of effect of each variable or items in explaining variance of scores of variable or main facto. In other word factor load shows degree of correlation of each observing variable (questions of questionnaire) with hidden variable (factors). Result of confirming factor analysis of variables showed that measurement model of variables is proper and all numbers and parameters are meaningful. Index of proportionality of measurement model is as below that shows properness of measurement model of variables. Result of measurement model denotes existence of positive and meaningful correlation between variables in the model. Regarding figure (1) we can observe factor loads of each questions of research. Amount of determination coefficient is a number between 0 and 1 that as it closes 1 amount of variance explaining becomes more. 


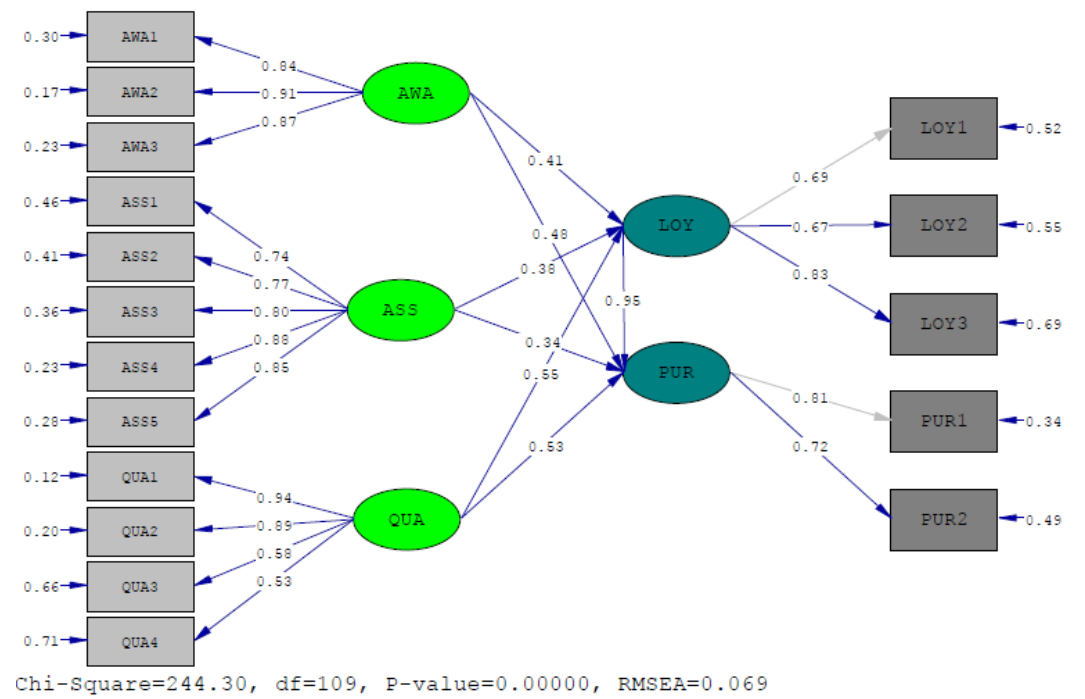

Fig 1: Research model in standard solution mode

\section{MODEL IN T-VALUE MODE}

Model solution in this mode is called t-value. Model in t-value or meaningful mode shows amount of $t$ statistics that is applied for judgment about meaningfulness of relations. If amount of $t$ statistics locates between +1.96 and -1.96 coefficients are not meaningful and lead to rejecting hypothesis and are meaningful in a state that is out of this limitation. These amounts in modes that are not meaningful are distinguished with red color. Figure (2) shows meaningfulness of coefficient and obtained parameters of the model that all coefficients have become meaningful. Regarding mentioned cases all hypotheis of research are confirmed. Result of considering hypothesis has been mentioned in table (3).

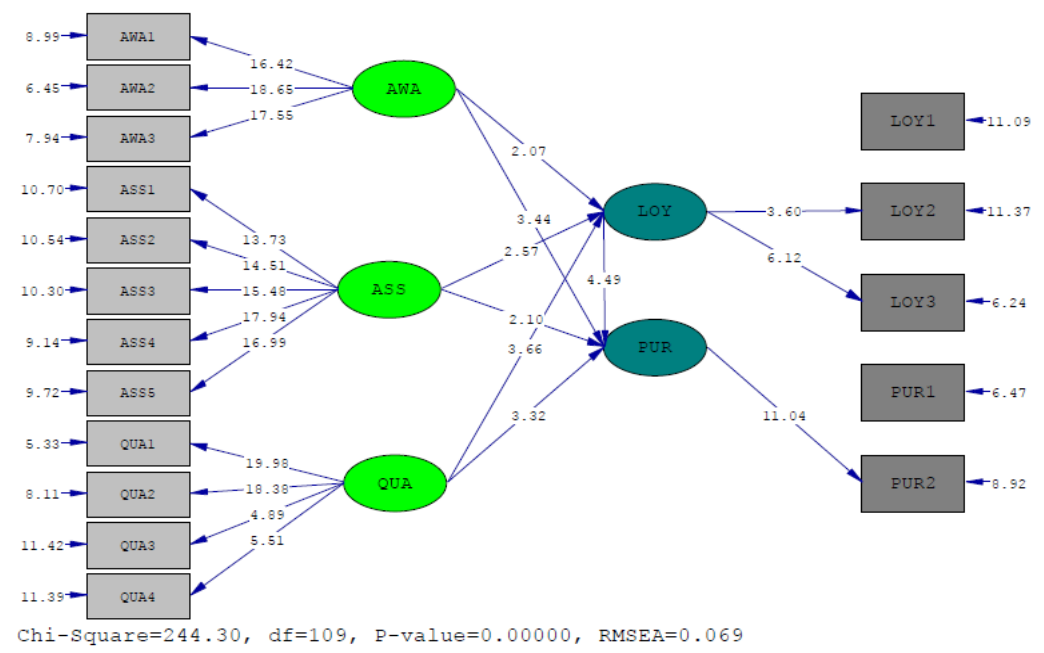

Fig (2): research model in meaningfulness coefficient mode

Table 3: Results of Hypothesis

\begin{tabular}{|l|r|r|c|}
\hline \multicolumn{1}{|c|}{ Hypothesis } & Sig & B & Conclusion \\
\hline Awareness of retailing has positive effect on customer shopping intention & 3.44 & 0.48 & Approved \\
\hline Awareness of retailing has positive effect on customer's loyalty & 2.07 & 0.41 & Approved \\
\hline Association of retailing has positive effect on customers loyalty & 2.57 & 0.38 & Approved \\
\hline Association of loyalty has positive effect on customers' shopping intention & 2.01 & 0.34 & Approved \\
\hline Perceived quality of retailing has positive effect on customers' loyalty & 3.66 & 0.53 & Approved \\
\hline Perceived quality of retailing has positive effect on customers' shopping & 3.32 & 0.55 & Approved \\
\hline
\end{tabular}




\begin{tabular}{|l|l|l|l|}
\hline intention. & & & \\
\hline $\begin{array}{l}\text { Customers' loyalty to retailing has positive effect on customers' shopping } \\
\text { intention }\end{array}$ & 4.49 & 0.95 & Approved \\
\hline
\end{tabular}

\section{CONCLUSION AND SUGGESTION}

Regarding confirmation of research hypothesis it is suggested marketing managers of Najm hypermarket use new facilities of contemporary era for awaring their main customers that are dependent to brand emotionally and by benefiting TV and radio communication, mobile phone, intent and any new method that may enhance this awareness. The most important point is that it is suggested this hypermarket strengthen his marketing activity in social network and seem benefits for customers who are member in these networks. Managers and marketers of najm hypermarket use strategy of increasing awareness of consumers for using services of these hypermarkets. For achieving this goal we can use strategy and policy ofactivitiesof integrated marketing communication such as brochures, billboards, activities of supporting sport and culture events, TV advertisement. Managers and marketers of Najm hypermarket in advertising strategy point their distinct performance than other hypermarkets. On the other hand regarding the third year of establishing this hypermarket as managers told it could take higher position comparing its competitors in the view of sale. Also it is suggested this hypermarket in strategic plans of marketing have many attention to leadership in market and strategy. Regarding positive and meaningful effect of brand association on shopping intention of customers it is suggested managers of Najm hypermarket strengthen this hypermarket and bymore awareness of customer provide field for association of hypermarket in mid of customers more. Top managers of Najm hypermarket have always consider changing interest in customers for presenting new services as present new services regarding interest of customers in this form that perceived services by customers is at the same level with expectation of customers or higher than it so that customers' perception of service quality increases. On the other hand it is suggested this hypermarket support his online shopping services extensively because in this section najm hypermarket in comparison with other hypermarkets has shown weaker performance. It is suggested considering more counter for payment so that expectation of customers decreases and seem progressive volume discount for customers who buy more goods than other customers, and in case customers shopping during a moth excess a distinct border another advantage like free consumption of some goods is considered.

\section{LIMITATION AND FUTURE SUGGESTIONS}

This research like any other research is not out of limitation, so researcher tried regarding limitations of research present some suggestions. In research model quality of perceived services of retailing has been considered as a first rank variable. It is suggested in future research quality of perceived services of retailing be considered regarding dimensions of tangibles, reliability, accountability, guarantee and sympathy. Another limitation of research is related to the subject that regarding that in this research only Najm hypermarket was considered, so in regard with strong capabilities of this hypermarket in generalizing result to other hypermarkets we should be careful. It is suggested in future research research model be tested in other hypermarkets of Rasht city. On the other hand regarding that in research model the effect of dimension of brand especial value in the view of Aker hat was changed by Das(2014) to especial value dimension of retailing may not provide all expected aspects of customer expectation about accountability and in case of existence of other variables it may achieve more exact result. It is suggested in future research consider the effect of variables like image of hypermarket, reliance to the hypermarket, shopping experience and personality of hypermarket on shopping intention and finally in this research customer' loyalty has been considered generally. It is suggested in future research researchers consider dimensions of behavioral loyalty and attitudinal loyalty and its effect on shopping intention. 


\section{REFERENCES}

1. Aghazadeh, A., Khalifeh, M., Samizadeh, M., Hosseini, S. M. (2013), Considering the combined role of sale promotions and customer relationship management on dimensions of brand especial value in the direction of increasing brandloyalty, business management, 5, 3, 1-18.

2. Ehsani, M., Javani, V. (2012), Considering effect of brand of successful teams on the degree of loyalty of followers at best league of Iran's football, applied research management and environmental science at sport, 2,89-98.

3. Parhizgar, M., Ebrahimi Abed, M. (2012).considering effect of dimension of brand especial value in Aker model on brand especial value in the view of consumer(case study:Samsung brand), business consideration, 53, 61-71.

4. Jalali Gorgani, M. T., Mehrani, H. (2013), "considering relationship of relation-oriented marketing method and repurchase behavior in chain shops of retailing at Gorgan",(researcher) management quarterly, 10,30, 57-72.

5. Jahandideh, B., Golmohammadi, A., Safdari Ranjbar, M. (2012), identification and prioritizing factors determine continuity of purchase of customers at etka hypermarket by using algorithm of neurotic networks", scientific-research quarterly of marketing research, 7, 122-150.

6. Hosseini, S. Y., Mousavi, S. A., Ziyaei Bideh, A. (2013), presenting a reason for explaining brand especial value based on staff of business insurance of Yazd province", scientific and research quarterly of new marketing research, 3, 1-16.

7. Dehdashti Shahrokh, Z., Seyed Mothari, S. M., Kajori, H. (2012), factors affecting brand especial value of insurance companies in the view of customers, insurance research letter(previous insurance industry), 27, 75-99.

8. Dehghani Soltani, M., Mohammadi, E., Pourashraf, Y., Sayeh Miri, K., Ghahri Shirin Abadi, E. (2013), Approach of structural equation modeling at explanation of experience effect, reliance and loyalty to brand on brand especial value, marketing management journal, No 21, 101-117.

9. Seyed Javadin, S. R., Shams, R. (2007), factors determining brand especial value of sport shoe among age group of adults, human and social science of management research letter, 7,73-96.

10.Ghasemi, P., Darzian Aziz, A. (2013), Considering effect of brand-orientation on brand performance and financial performance of company at active companies in Ahvas industrial city, marketing management journal, 18, 75-90.

11.Kia, A. (2012), Considering effect of association of company's ability and awareness of brand on tendency to repurchase and the mediating role of perception of product quality and brand association at the process of purchase decision-making, marketing management journal, 14, 89-103.

12.Chitcharo, N., Chaisak., K., Penjuree., W., Kanokorn, B., Kanthawongs, P. (2013), A Model to Investigate the Influence of Channel, Perceived Web Quality, Brand Awareness, Perceived Quality on After-Sales Service of the All-In-One Office Products, Social and Behavioral Sciences, 88, 8-12.

13. Chopra, K. (2014), "Empirical study on role of customer service in delivering satisfaction at branded retail outlets in Pune", Economics and Finance, 11, 239-246.

14.Das, G. (2013), Impacts of retail brand personality and self-congruity on store loyalty: the moderating role of gender, Journal of Retailing and Consumer Services, 21, 130-138.

15.Das, G. (2014). Linkages of retailer awareness, retailer association, and retailer perceived quality and retailer loyalty with purchase intention: A study of Indian food retail brands, Journal of Retailing and Consumer Services, 21, 284-292.

16.Hsu, M., Chang, C., Chuang, L. (2015), Understanding the determinants of online repeat purchase intention and moderating role of habit: The case of online group-buying in Taiwan", International Journal of Information Management, 35, 45-56.

17.Ihtiyar, A., Ahmad, F. (2014), Intercultural Communication Competence as a Key Activator of Purchase Intention, Procedia-Social and Behavioral Sciences, 150, 590-599.

18.Kamaruddin, R., Osman, I., Che, P., Che, A. (2015), Public Transport Services in Klang Valley: Customer Expectations and Its Relationship Using SEM", Social and Behavioral Sciences, 36, 431438. 
19.Kim, A. J., Ko, E. (2012), Do social media marketing activities enhance customer equity? An empirical study of luxury fashion brand, Journal of Business Research, 65, 1480-1486.

20.Lu, L., Chang, W., Chang, H. (2015), Consumer attitudes toward blogger's sponsored recommendations and purchase intention: The effect of sponsorship type, product type, and brand awareness, Computers in Human Behavior, 34, 258-266.

21.Moller, J., Herm, S. (2013), Shaping retail brand personality perceptions by bodily experiences, Journal of Retailing and Consumer Services, 89, 438-446.

22.Muhamad, Y., Noor, S., Wan, R., Wan, E., Mohd, A., Norafifa. C., Mohd Rashid, N. (2014), Muslim's Purchase Intention towards Non-Muslim's Halal Packaged Food Manufacturer, Procedia Social and Behavioral Sciences, 130, 145-154.

23.Santos-Vijande, M., Del Río- Lanza, A., Suárez-Álvarez, L., Díaz-Martín, A. (2013), The brand management system and service firm competitiveness, Journal of Business Research, 66, 2, 148-157.

24.Wu, L. (2011), Satisfaction, inertia, and customer loyalty in the varying levels of the zone of tolerance and alternative attractiveness, Journal of Services Marketing, 25, 5, 310-322.

25.Wu, P., Yeh, G. Y., Hsiao, C. (2015), The effect of store image and service quality on brand image and purchase intention for private label brands, Australasian Marketing Journal, 19, 30-39.

26. Yildirim, Y., Aydin, K. (2012), The role of popular tv series and tv series characters in creating brand awareness, Social and Behavioral Sciences, 62, 695-705. 